\title{
Characteristics of Atmospheric Compositions in the Background Area of Yangtze River Delta during Heavy Air Pollution Episode
}

\author{
Hong-Hui Xu, ${ }^{1}$ Jing-Jiao Pu, ${ }^{1}$ Jun He, ${ }^{2}$ Jie Liu, ${ }^{1}$ Bing Qi, ${ }^{3}$ and Rong-Guang $\mathrm{Du}^{3}$ \\ ${ }^{1}$ Zhejiang Meteorological Science Institute, Hangzhou 310008, China \\ ${ }^{2}$ Department of Chemical and Environmental Engineering, University of Nottingham Ningbo China, Ningbo 315100, China \\ ${ }^{3}$ Hangzhou Meteorological Bureau, Hangzhou 310051, China
}

Correspondence should be addressed to Jing-Jiao Pu; pujingjiao@hotmail.com and Jun He; jun.he@nottingham.edu.cn

Received 14 January 2016; Revised 14 March 2016; Accepted 23 March 2016

Academic Editor: Jiyi Lee

Copyright (C) 2016 Hong-Hui Xu et al. This is an open access article distributed under the Creative Commons Attribution License, which permits unrestricted use, distribution, and reproduction in any medium, provided the original work is properly cited.

\begin{abstract}
In order to understand the formation and evolution of recurrent severe haze pollution episodes in Yangtze River Delta, China, a short comparative sampling campaign was conducted at the Lin'an background monitoring station from 25 November 2013 to 14 December 2013. The characteristic concentrations of $\mathrm{PM}_{2.5}$, black carbon, $\mathrm{CO}_{2}, \mathrm{CO}$, and $\mathrm{CH}_{4}$ have been systematically recorded at the abovementioned site. Coupled with detailed analysis of air backward trajectories, fire spot distribution surrounding the studied site and meteorological impacts, temporal trend, diurnal variation, and intercorrelation of the aforementioned species have also been comprehensively investigated throughout prehaze, haze, and posthaze periods.
\end{abstract}

\section{Introduction}

Due to the fast industrialization in China, severe haze pollution episodes have occurred more frequently in the past few years, especially in Yangtze River Delta [1-4], Pearl River Delta [5-7], and North China Plain [8-10], and they have attracted more and more concern because they not only reduce atmospheric visibility but also pose great health threats to human beings [11-14]. A number of studies have been conducted to investigate the formation of haze and characteristics of the ambient aerosols worldwide. The previous researches found out that the formation of secondary aerosol was one of the important mechanisms of haze occurrence, and meteorological factors including stagnant atmospheric condition, weak surface wind speed, and strong temperature inversion in the planetary boundary layer (PBL) allowing pollutants to accumulate in a shallow layer were another main contributor to haze episodes $[3,10,15]$. The water soluble components in the airborne particles could be used to explore the key causes of haze formation in urban areas $[1,8,16]$. In Yangtze River Delta (YRD), many researches have been carried out on the correlation between aerosol plus gas concentrations (e.g., $\mathrm{PM}_{2.5}, \mathrm{SO}_{2}, \mathrm{NO}_{x}, \mathrm{CO}$, and $\mathrm{O}_{3}$ ) and other chemical composition of these fine aerosols in order to better understand the formation mechanism of haze aerosols [2$4,17]$. Fu et al. [2] reported that much higher concentration of secondary aerosol particles was observed on the heavily polluted day and the unusual stagnant dispersion condition played a predominant role in causing such a severe pollution. Huang et al. [17] studied several extreme low visibility periods by a synergy of ground-based monitoring and satellite and lidar observations and identified three typical haze types in Shanghai, that is, secondary inorganic pollution, dust, and biomass burning. Kang et al. [3] found that large-scale stagnation occurred in a long-lasting haze episode in Nanjing and high ratio of $\mathrm{NO}_{3}{ }^{-} / \mathrm{SO}_{4}{ }^{2-}$ indicated that traffic emission could be one of the main sources in the YRD region.

It is known that the mass concentration ratios of various atmospheric pollutants measured at the same site could indicate their different origins such as anthropogenic and biogenic sources [18-21]. BC is amorphous carbon produced by incomplete combustion of carbonaceous materials, mainly from vehicle emissions, industrial combustion, residential burning, biomass burning, power plants, and so forth [22]. 
$\mathrm{CO}_{2}$ and $\mathrm{CH}_{4}$ are two types of important greenhouse gases. $\mathrm{CO}_{2}$ primarily derives from fossil fuel combustion, cement production, and land use change, while $\mathrm{CH}_{4}$ mainly comes from ruminant animals, wetlands, rice paddies, energy production, landfills, biomass burning, and biogenic sources [23]. CO is an indirect greenhouse gas, which comes from vehicle exhaust and other incomplete combustion processes [24]. The correlations of concentrations of $\mathrm{BC}, \mathrm{CO}_{2}$, and $\mathrm{CO}$ showed that $\Delta \mathrm{CO} / \Delta \mathrm{CO}_{2}$ (regression slope of $\mathrm{CO} / \mathrm{CO}_{2}$ ) could present combustion efficiency of emission sources and the chief source might be identified based on the specific $\mathrm{CO} / \mathrm{CO}_{2}$ emission ratio of different emission sources $[25,26]$. Besides, $\triangle \mathrm{BC} / \Delta \mathrm{CO}$ could also be affected by fuel composition and the types of combustion [27-30]; for instance, the $\mathrm{BC} / \mathrm{CO}$ emission ratio became higher from those more carbon contained fuel when the combustion condition remained the same as the larger $\mathrm{BC}$ fraction in $\mathrm{PM}_{2.5}$ could be produced [31] and the emission intensity of $\mathrm{BC}$ and $\mathrm{CO}$ would differ significantly under flaming or smoldering condition for the same fuel (e.g., vegetation fire) [32]. Moreover, $\Delta B C / \Delta C O$ could imply the possible loss of $\mathrm{BC}$ during atmospheric transport as $\mathrm{BC}$ is easier to be removed by dry or wet deposition, especially in the marine boundary layer $[19,33$, 34]. Atmospheric measurements of carbonaceous aerosols in China in recent years have provided useful information about their characteristics and relevant processes responsible for their variability and contribution to haze formation [35-38]. However, most of the reports focused on urban areas and might not be representative sufficiently of regional conditions. In addition, very few studies in China have attempted to evaluate the particulate and carbonaceous aerosols measured simultaneously with other relevant trace gaseous species during heavy aerosol pollution events especially in YRD region.

Therefore, in this study, Global Atmospheric Watch (GAW) station of Lin'an regional background site has been chosen for a short yet comparative sampling campaign between nonhaze and haze episodes from late Nov. 2013 to early Dec. 2013. This location is in the suburb of Linan City, typical of nonurban environment in YRD, and the comparative sampling on this site was deemed beneficial to understanding more of regional characteristics of such aerosols during both nonhaze and severe haze pollution episodes. According to the air quality index (AQI) released by the Environmental Protection Bureau (EPB) of Zhejiang Province, Hangzhou experienced mild haze on 1 Dec., moderate haze on 2 3 Dec., and severe haze from 4 to $9 \mathrm{Dec}$., and the haze degraded back to mild on 10 11 Dec. During this haze episode, the hourly mean concentration of $\mathrm{PM}_{2.5}$ reached up to $394 \mu \mathrm{g} \mathrm{m}^{-3}$ in Hangzhou, which was the highest value in 2013. Compared with another polluted event which occurred in Jan. 2013, this haze event persisted longer and appeared to be much more severe [39]. In this report, the characteristic concentrations of $\mathrm{PM}_{2.5}, \mathrm{BC}, \mathrm{CO}_{2}, \mathrm{CO}$, and $\mathrm{CH}_{4}$ have been systematically measured in situ. Coupled with detailed analysis of air backward trajectories, fire spot distribution surrounding the studied site and meteorological impacts, temporal trend, diurnal variation, and intercorrelation of the abovementioned species have also been comprehensively investigated throughout prehaze, haze, and posthaze periods, which could shed light on the evolution of these species and their important roles in the formation of such a severe haze episode in this regional background area.

\section{Experimental}

2.1. Sampling. The sampling site is located at the WMO Lin'an Regional Atmospheric Background Station $\left(119^{\circ} 44^{\prime} \mathrm{E}\right.$, $\left.30^{\circ} 18^{\prime} \mathrm{N}, 138.6 \mathrm{masl}\right)$, which is in the southern part of Yangtze River Delta, about $60 \mathrm{~km}$ away to the west of Hangzhou and about $150 \mathrm{~km}$ away to the southwest of Shanghai. The station is surrounded by hilly lands, forest, and farming areas, with heavy vegetation coverage. There is no large village around within $3 \mathrm{~km}$. The prevailing wind direction is northeast and southwest. Special weather phenomenon rarely occurs and the frequency of thermal inversion is low, with distinct meteorological characteristics of subtropical monsoon climate and atmospheric circulation.

The equipment for in situ observation of $\mathrm{PM}_{2.5}$ was TEOM 1405-D (Thermo Fisher Scientific). The sampling flow rate was $3 \mathrm{~L} \mathrm{~min}^{-1}$, and the time interval of measurement was 5 minutes. This monitor takes a direct mass measurement of particulates using a tapered element oscillating microbalance (TEOM) to measure the mass change of sample filters onto which particles impinge. The observation instrument of $\mathrm{BC}$ was Aethalometer AE-31 (American Magee Scientific). There are seven wavelengths that could be used for observations, $370 \mathrm{~nm}, 470 \mathrm{~nm}, 520 \mathrm{~nm}, 590 \mathrm{~nm}, 660 \mathrm{~nm}, 880 \mathrm{~nm}$, and $950 \mathrm{~nm}$, respectively. The sampling flow rate was $5 \mathrm{~L} \mathrm{~min}^{-1}$ with $2.5 \mu \mathrm{m}$ impactor in the air inlet and the time interval was 5 minutes. The instrument aspirates ambient air using its inlet tube and black carbon mass concentration is estimated by measuring the change in the transmittance of a quartz filter tape with and without particles collected. These data are automatically recorded in the flash card of the instrument and displayed on the screen. The data analyzed here was observed from the $880 \mathrm{~nm}$ channel [40]. $\mathrm{CO}_{2}$ and $\mathrm{CH}_{4}$ concentrations were measured by $\mathrm{CO}_{2} / \mathrm{CH}_{4}$ analyzer (Picarro G1301), while $\mathrm{CO}$ concentration was measured by $\mathrm{CO}_{2} / \mathrm{CO}$ analyzer (Picarro G1302). The measuring technique is based on cavity ring-down spectroscopy. The device comprises three main parts: a laser, a high finesse optical cavity with two or more mirrors, and a photodetector. The laser light is injected into the cavity through one partially reflecting mirror. This light builds up over time in the cavity and is monitored by a photodetector through a second partially reflecting mirror. After the laser is rapidly turned off, most of the light remains trapped in the cavity, and the decaying light intensity due to cavity mirror loss as well as sample absorption and scattering is measured. The limit of detection of $\mathrm{CO}_{2}, \mathrm{CH}_{4}$, and $\mathrm{CO}$ measured with this technique is lower than $0.05 \mathrm{ppm}, 0.7 \mathrm{ppb}$, and $5 \mathrm{ppb}$ per $5 \mathrm{~min}$, respectively; the value of maximum drift peak reaches $0.5 \mathrm{ppm}, 3 \mathrm{ppb}$, and $50 \mathrm{ppb}$ per month, respectively. The time interval of measurement is 4 seconds. The more detailed descriptions of the whole analytical system can be found in Fang et al. [41, 42]. The above five colocated 
measurements were conducted simultaneously from $25 \mathrm{Nov}$. to 14 Dec. 2013.

The hourly meteorological data, including visibility, relative humidity, and surface wind speed, was collected from the meteorological observation devices deployed within Linan station. Wind speed was observed at $10 \mathrm{~m}$ above the ground and relative humidity was collected at $1.5 \mathrm{~m}$ above the ground. Visibility was monitored by FD12 forward scatter visibility meter (Vaisala Corporation, Finland).

2.2. Quality Control. For the $\mathrm{PM}_{2.5}$ and $\mathrm{BC}$ measurements, the calibration of the flow rate was done biweekly at normal condition. However, when it became noisy during continuous operation, the flow rate was calibrated accordingly and the outliers were excluded from analysis.

For the $\mathrm{CO}_{2}, \mathrm{CH}_{4}$, and $\mathrm{CO}$ measurements, the calibration of the observation system was conducted regularly every 12 hours by measuring a set of standard working gases which are traceable to WMO/GAW standard gas of level one, and concentrations were corrected slightly from these calibrations [41, 42]. In addition, the outliers were also excluded according to the equipment performance log when there were instrument troubles or anthropogenic influences, such as instrument maintenance or on-site visit.

Routine maintenance for the meteorological instruments was carried out regularly so that the quality of observations would not deteriorate significantly. Routine quality control checks were also conducted to detect the equipment faults.

\section{Results and Discussion}

3.1. Air Mass backward Trajectory Analysis. Figure 1 illustrated the active fire locations monitored by MODIS instrument on Satellite Terra (transit time in the day is around 10:30 local time) and Aqua (transit time in the day is around 13:30 local time) of USA NASA [43], and the $96 \mathrm{hr}$ air mass backward trajectories of Linan station with an interval of 3 hours at $500 \mathrm{~m}$ (agl) from 25 Nov. to $15 \mathrm{Dec}$. were calculated by Hysplit 4.9 model from NOAA (Draxler and Rolph). The input meteorological data of trajectory model was from Global Data Assimilation System (GADS) of NOAA. The statistically mean trajectories with their relative percentage shown have been adopted to represent the pathways of each cluster for a more concise presentation by merging through the Euclidean calculation.

During the prehaze period (25-30 Nov. 2013), the air mass over the sampling site mainly originated from the northwest sector, $41.7 \%$ of the $96 \mathrm{~h}$ backward trajectories passing through Inner Mongolia, Shanxi, Henan, and Anhui provinces to Linan, with the rest $58.3 \%$ trajectories coming through Gansu, Ningxia, Shanxi, Henan, and Anhui before reaching the studied site. During this period, trajectories were observed to pass through the north China plain with heavy industries but fewer fire spots distributed in the northwest sector (Figure 2). During the haze period (4-9 Dec. 2013), the $96 \mathrm{~h}$ backward trajectories transported much shorter distance, indicating more stagnant meteorological condition in the surrounding area of the receptor site, $57.5 \%$ coming from Henan passing through Anhui and reaching Linan and another $42.5 \%$ circling over Jiangxi and Zhejiang provinces in the southwest sector, where the daily average number of fire spots increased dramatically (Figure 2), indicating much stronger biomass burning contribution to the air mass over the receptor site through short-range transport. In the posthaze period (10-14 Dec. 2013), the majority of air masses originated from the northwest sector, while the density of fire spot surrounding the sampling site had decreased significantly.

Apparently, based on both air mass backward trajectory and fire spot distribution, it could be inferred that the air quality in the studied site had been affected by the air parcels coming from biomass burning regions via the short- and medium-range transport particularly during the haze episode in addition to the regular industrial activities and traffic emissions.

3.2. Temporal Trends of $P M_{2.5}$ and $B C$. Figure 3 shows the hourly mean mass concentration of $\mathrm{PM}_{2.5}$ at Lin'an regional background station from 25 Nov. to 14 Dec. 2013. Before 1 Dec. 2013, the average $\mathrm{PM}_{2.5}$ concentration was $30.4 \pm$ $10.0 \mu \mathrm{g} \mathrm{m}^{-3}$, lower than $75 \mu \mathrm{g} \mathrm{m}^{-3}$, which is the daily average healthy threshold for residential area and countryside defined in the latest China's National Air Quality Standard (GB30952012). After that the $\mathrm{PM}_{2.5}$ level started to increase, stayed above $75 \mu \mathrm{g} \mathrm{m}^{-3}$ from 15:00 on 3 Dec. to 15:00 on 9 Dec., and exceeded $250 \mu \mathrm{g} \mathrm{m}^{-3}$ at the periods of 16:00-21:00 on 6 Dec., 11:00-22:00 on 7 Dec., and 16:00-18:00 on 8 Dec. It was clearly showing that a severe haze pollution event hit the sampling site during 4 9 Dec. 2013 strongly with $\mathrm{PM}_{2.5}$ of $162.5 \pm 66.6 \mu \mathrm{g} \mathrm{m}^{-3}$, and the air quality in terms of particulate level deteriorated most from 6 to 8 Dec. 2013 with $\mathrm{PM}_{2.5}$ of $203.3 \pm 71.0 \mu \mathrm{g} \mathrm{m}^{-3}$. The particle concentration trend was consistent with the AQI published by Zhejiang Provincial Environmental Protection Bureau (http://www.zjepb.gov.cn/ hbtmhwz/index.htm), for which $\mathrm{PM}_{2.5}$ was also categorized as the primary pollutant during this study period.

It can also be seen from Figure 3 that the mass ratio of $\mathrm{PM}_{2.5}$ in $\mathrm{PM}_{10}\left(\mathrm{PM}_{2.5} / \mathrm{PM}_{10}\right)$ at Lin'an background station started to rise from 1 Dec. 2013 with the average ratio of 63.6 $\pm 5.6 \%$ during 1 3 Dec. 2013. Afterwards, the mean ratio of $\mathrm{PM}_{2.5} / \mathrm{PM}_{10}$ kept on increasing and reached $70.7 \pm 5.6 \%$ during severely polluted period of 4 9 Dec. 2013, which was nearly close to the value observed in Shanghai during another large-scale haze pollution episode that happened in YRD in January 2013 [39]. During the prehaze (25 30 Nov. 2013) and posthaze (10 14 Dec. 2013) periods, the mean ratios of $\mathrm{PM}_{2.5} / \mathrm{PM}_{10}$ were $42.7 \pm 11.2 \%$ and $56.1 \pm 6.7 \%$, respectively. This trend demonstrated that more $\mathrm{PM}_{2.5}$ had been formed and contributed to the inhalable particulate matter during the heavy haze period from 1 to 9 Dec. 2013 in terms of both mass concentration and mass ratio of $\mathrm{PM}_{2.5} / \mathrm{PM}_{10}$, which might explain that much stronger secondary aerosol formation and accumulation could occur including secondary organic and inorganic aerosols during such a haze pollution event in this studied region [44].

Figure 4 presented the scatter distribution of hourly mean concentrations of $\mathrm{BC}$ and $\mathrm{PM}_{2.5}$ at Lin'an background station 


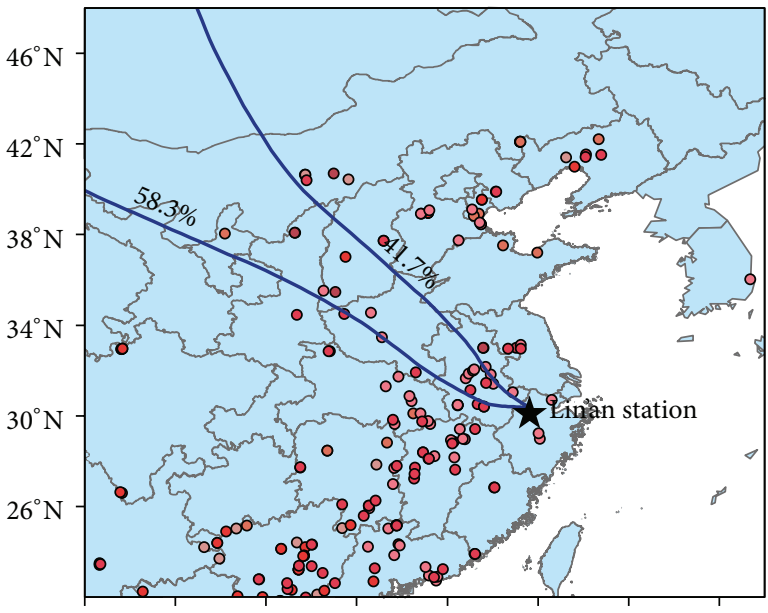

$100^{\circ} \mathrm{E} \quad 104^{\circ} \mathrm{E} \quad 108^{\circ} \mathrm{E} \quad 112^{\circ} \mathrm{E} \quad 116^{\circ} \mathrm{E} \quad 120^{\circ} \mathrm{E} \quad 124^{\circ} \mathrm{E} \quad 128^{\circ} \mathrm{E}$

(a)

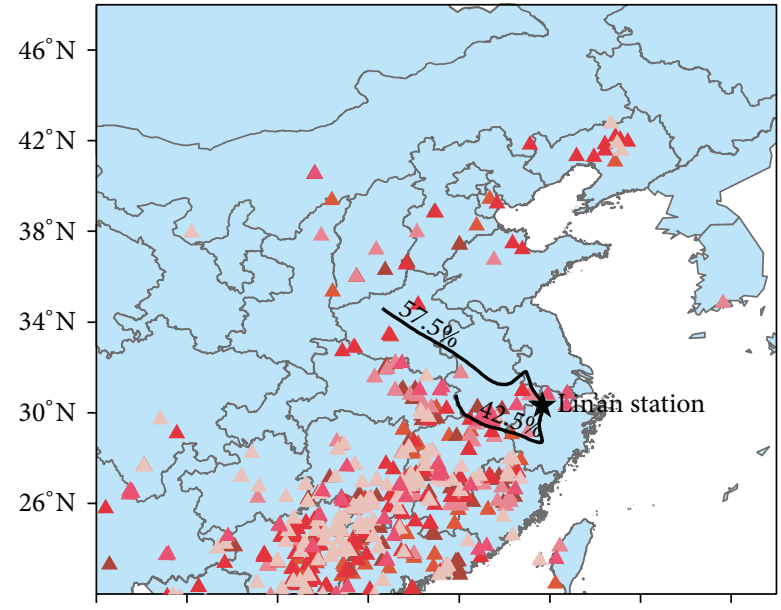

$100^{\circ} \mathrm{E} \quad 104^{\circ} \mathrm{E} \quad 108^{\circ} \mathrm{E} \quad 112^{\circ} \mathrm{E} \quad 116^{\circ} \mathrm{E} \quad 120^{\circ} \mathrm{E} \quad 124^{\circ} \mathrm{E} \quad 128^{\circ} \mathrm{E}$

(b)

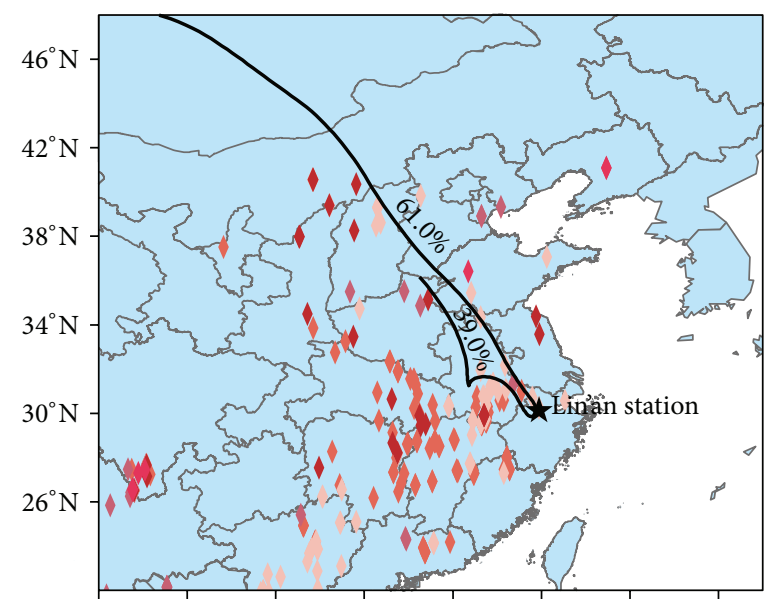

$100^{\circ} \mathrm{E} \quad 104^{\circ} \mathrm{E} \quad 108^{\circ} \mathrm{E} \quad 112^{\circ} \mathrm{E} \quad 116^{\circ} \mathrm{E} \quad 120^{\circ} \mathrm{E} \quad 124^{\circ} \mathrm{E} \quad 128^{\circ} \mathrm{E}$

(c)

Figure 1: Active fire locations and $96 \mathrm{hr}$ air mass backward trajectories of Lin'an station. (a) Prehaze period (25 30 Nov. 2013), (b) haze period (4 9 Dec. 2013), and (c) posthaze period (10 14 Dec. 2013).

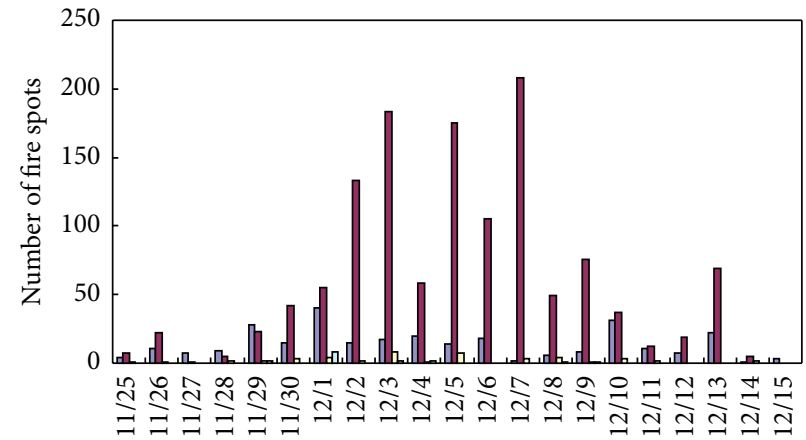

Date

$\begin{array}{ll}\square \text { Northwest } & \square \text { Northeast } \\ \square \text { Southwest } & \square \text { Southeast }\end{array}$

Figure 2: Daily numbers of fire spots in different sectors: northwest sector: $100^{\circ} \mathrm{E}-119.733^{\circ} \mathrm{E}, 30.3^{\circ} \mathrm{N}-48^{\circ} \mathrm{N}$; southwest sector: $100^{\circ} \mathrm{E}-119.733^{\circ} \mathrm{E}$, $22^{\circ} \mathrm{N}-30.3^{\circ} \mathrm{N}$; northeast sector: $119.733^{\circ} \mathrm{E}-130^{\circ} \mathrm{E}, 30.3^{\circ} \mathrm{N}-48^{\circ} \mathrm{N}$; and southeast sector: $119.733^{\circ} \mathrm{E}-130^{\circ} \mathrm{E}, 22^{\circ} \mathrm{N}-30.3^{\circ} \mathrm{N}$. 


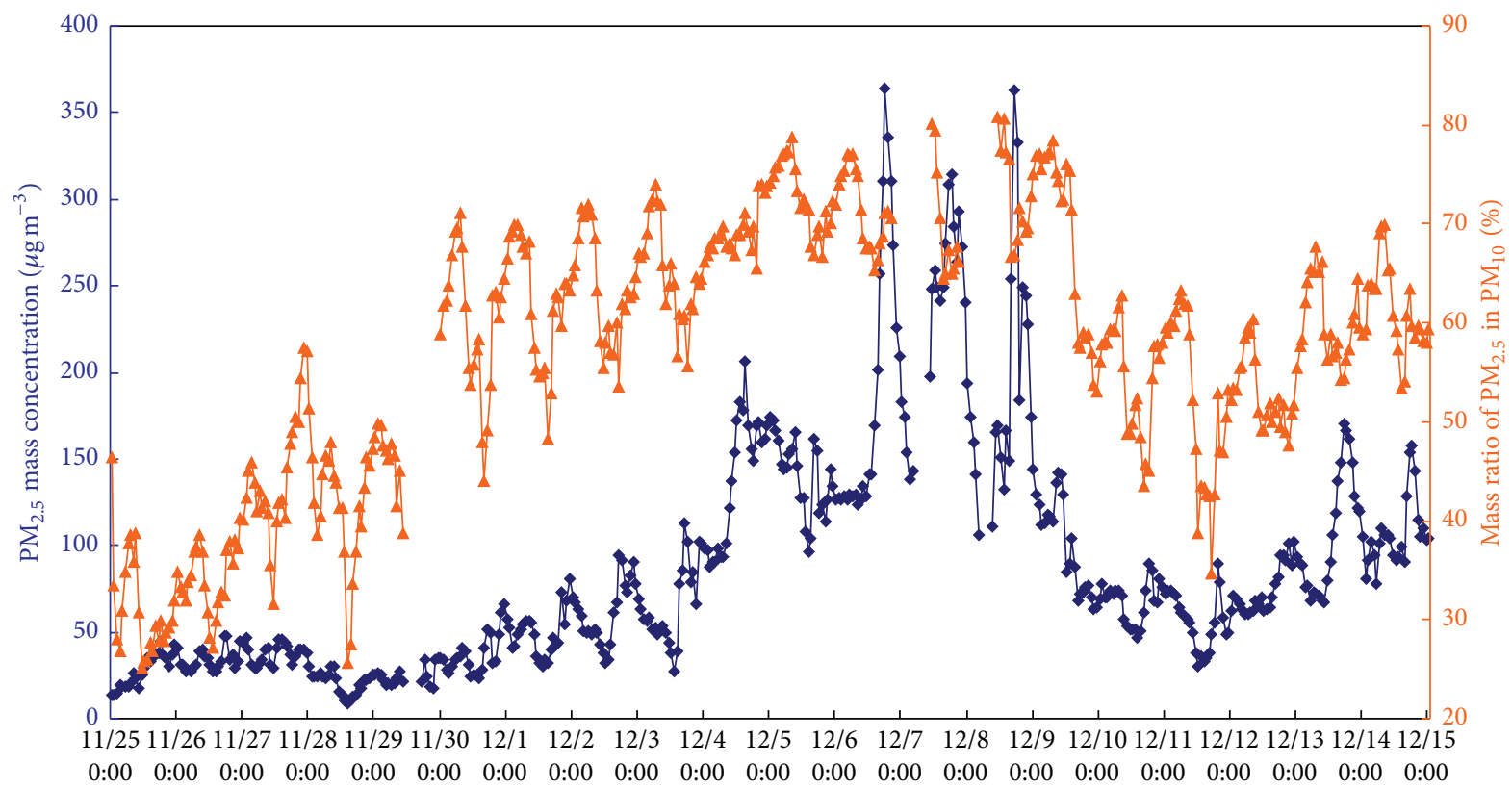

Local time

$$
\begin{aligned}
& \multimap \mathrm{PM}_{2.5} \\
& \leftarrow \mathrm{PM}_{2.5} / \mathrm{PM}_{10}
\end{aligned}
$$

Figure 3: Hourly mean mass concentration of $\mathrm{PM}_{2.5}$ and mass proportion of $\mathrm{PM}_{2.5}$ in $\mathrm{PM}_{10}$ at Lin'an regional background station.

during three periods: prehaze period (25 30 Nov. 2013), haze period (4 9 Dec. 2013), and posthaze period (10 14 Dec. 2013). The temporal concentration trends of both $\mathrm{BC}$ and $\mathrm{PM}_{2.5}$ seemed very consistent, and the square of correlation coefficient of concentrations of $\mathrm{BC}$ and $\mathrm{PM}_{2.5}$ was up to 0.58 (prehaze period), 0.79 (haze period), and 0.86 (posthaze period), respectively, with $99 \%$ confidence interval. As for the fact that it is well known that BC is essentially a primary pollutant emitted from various combustion processes, the high correlation coefficient of concentrations of $\mathrm{BC}$ and $\mathrm{PM}_{2.5}$ during haze period indirectly confirmed that $\mathrm{BC}$ was emitted from the similar sources to those precursors which contributed largely to the formation of $\mathrm{PM}_{2.5}$ in this region. The mass ratio of $\mathrm{BC}$ in $\mathrm{PM}_{2.5}$ accounted for $8.03 \pm 2.46 \%$, $6.99 \pm 0.91 \%$, and $8.95 \pm 1.40 \%$ in prehaze, haze, and posthaze periods, respectively. It can be clearly seen that the mass proportion of $\mathrm{BC}$ in $\mathrm{PM}_{2.5}$ was lower during haze period, which was also observed in other cities of China, such as Shanghai and Guangzhou, where the significant increase of secondary species caused the haze days $[6,39]$.

3.3. Temporal Trends of $\mathrm{CO}_{2}, \mathrm{CO}$, and $\mathrm{CH}_{4}$. Both $\mathrm{CO}_{2}$ and $\mathrm{CO}$ are directly and indirectly related with the emission from combustion of fossil fuels (oil, natural gas, and coal), solid waste, biomass (e.g., wood products) and with various industrial processes (e.g., cement kilns); $\mathrm{CH}_{4}$ is mainly released through agricultural practices including livestock, biomass burning, and the decay of landfill wastes, though it could also be emitted during the production and transport of fossil fuels (e.g., natural gas).
Figure 5 describes the hourly mean concentrations of $\mathrm{CO}_{2}, \mathrm{CO}$, and $\mathrm{CH}_{4}$ at Linan background station from 25 Nov. to 14 Dec. 2013. Before 1 Dec., the occurrence levels of $\mathrm{CO}_{2}, \mathrm{CO}$, and $\mathrm{CH}_{4}$ maintained their concentrations below $420.7 \mathrm{ppm}, 0.54 \mathrm{ppm}$, and $2.00 \mathrm{ppm}$, respectively. From $1 \mathrm{Dec}$. to 3 Dec., they started to increase gradually and reached the peak of $429.6 \mathrm{ppm}\left(\mathrm{CO}_{2}\right), 0.82 \mathrm{ppm}(\mathrm{CO})$, and $2.07 \mathrm{ppm}$ $\left(\mathrm{CH}_{4}\right)$, respectively. During the period of $4 \sim 9$ Dec., concentrations of these pollutants jumped noticeably, especially from 16:00 on $6 \mathrm{Dec}$. to 10:00 on $8 \mathrm{Dec}$., with the peak values of $494.2 \mathrm{ppm}\left(\mathrm{CO}_{2}\right), 2.18 \mathrm{ppm}(\mathrm{CO})$, and $2.45 \mathrm{ppm}\left(\mathrm{CH}_{4}\right)$, respectively. The occurrence levels of these three pollutants decreased to $427.8 \pm 9.6 \mathrm{ppm}\left(\mathrm{CO}_{2}\right), 0.78 \pm 0.19 \mathrm{ppm}(\mathrm{CO})$, and $2.07 \pm 0.06 \mathrm{ppm}\left(\mathrm{CH}_{4}\right)$ during the posthaze period of $10 \sim$ 14 Dec., though the haze had not degraded completely. This occurrence trend was generally consistent with that of $\mathrm{PM}_{2.5}$ and BC mentioned above. The spikes and trends of these three atmospheric gases during this sampling period could be attributed to the following factors: (1) besides the regular industrial activities, the fire spots in surrounding region may have some effect especially during the haze period when the emission intensity could be strengthened, which was verified by the analysis in Section 3.1; (2) stagnant atmospheric condition would contribute to the stronger accumulation of these pollutants, for which more details could be found in Section 3.4.

3.4. Meteorological Effects on Temporal Trends of Concerned Pollutants. During the sampling period from 25 Nov. to 14 Dec., no precipitation was observed at Linan station, and 


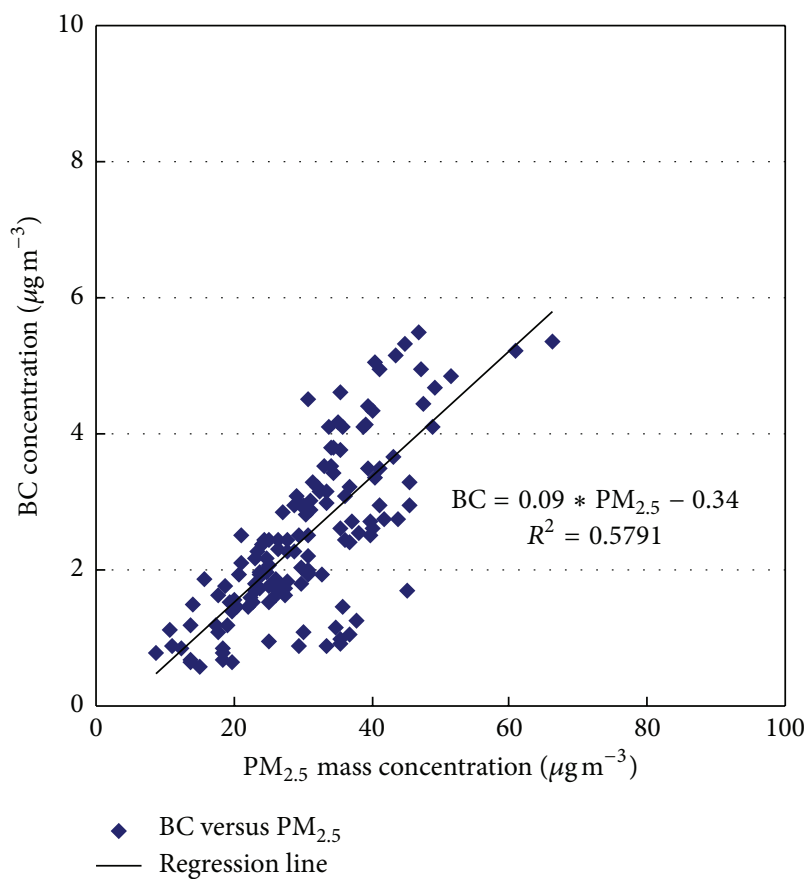

(a)

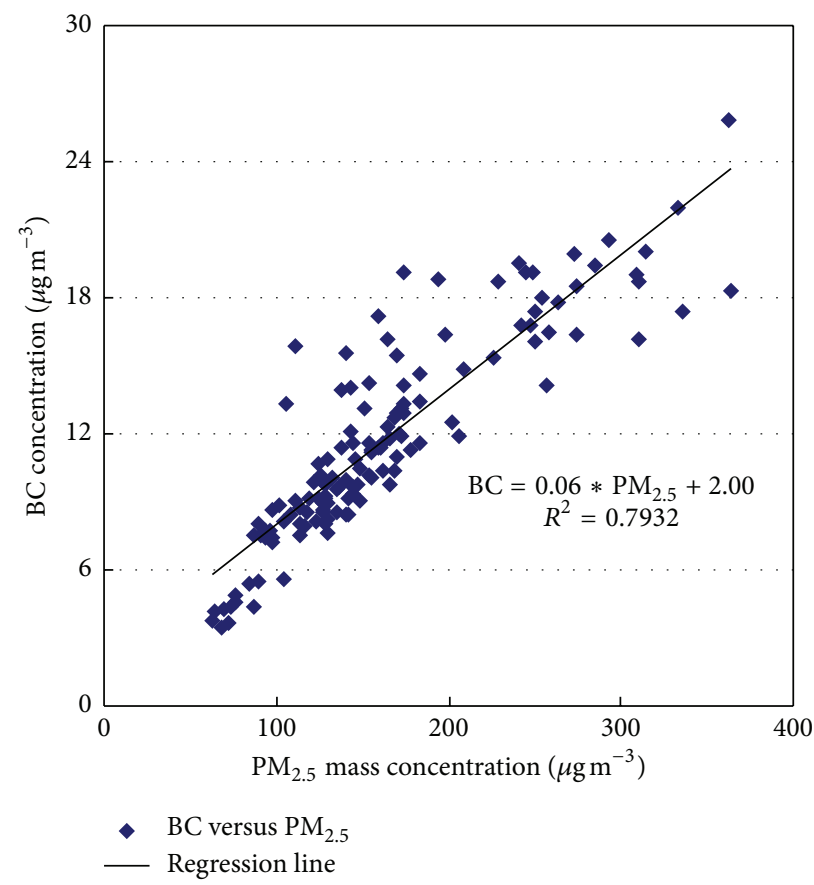

(b)

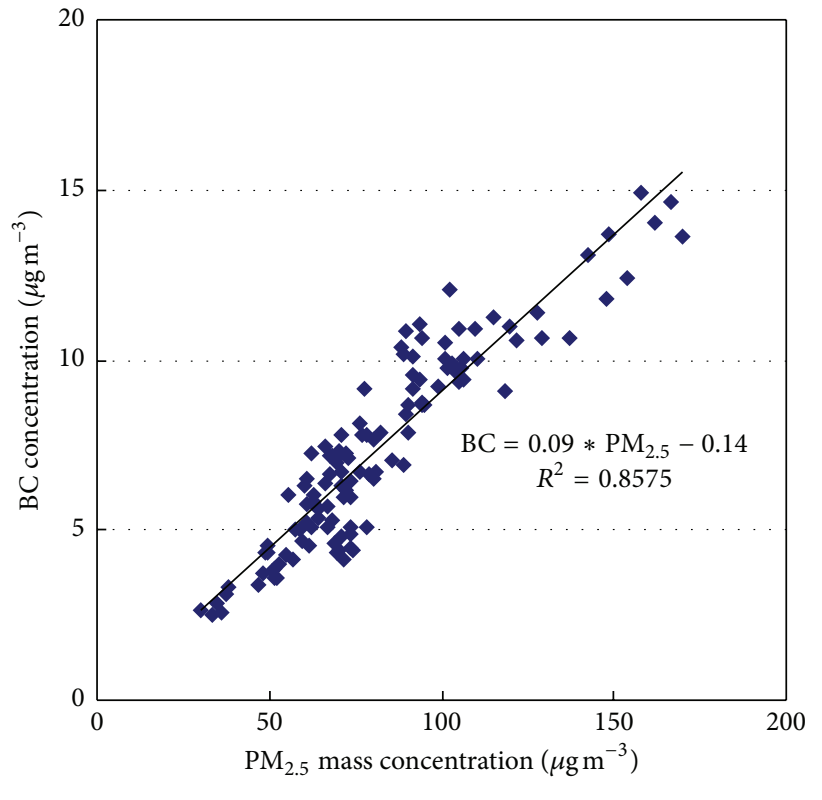

- BC versus $\mathrm{PM}_{2.5}$

- Regression line

(c)

FIGURE 4: Scatter distribution of hourly mean concentrations of $\mathrm{BC}$ and $\mathrm{PM}_{2.5}$ at Lin'an background station: (a) prehaze period, (b) haze period, and (c) posthaze period.

relative humidity $(\mathrm{RH})$ was lower than $80 \%$ at most of the time. The result in Figure 6 had shown a very clear temporal trend that the visibility was mostly more than $10 \mathrm{~km}$ during the prehaze period, dropped down to less than $5 \mathrm{~km}$ during the strong haze episode, and improved to some extent from 11 Dec. 2013. It needs to be pointed out that fog occurred during two periods of 21:00 on 6 Dec. 11:00 on 7 Dec. and 22:00 on 7 Dec. 9:00 on 8 Dec. when $\mathrm{RH}$ exceeded $80 \%$ and visibility fell down below $1 \mathrm{~km}$ (Figure 6). The visibility reduction could be attributed to the light extinction by both water vapor and haze aerosols during the above two slots. However, due to the wet scavenging of particles by fog 


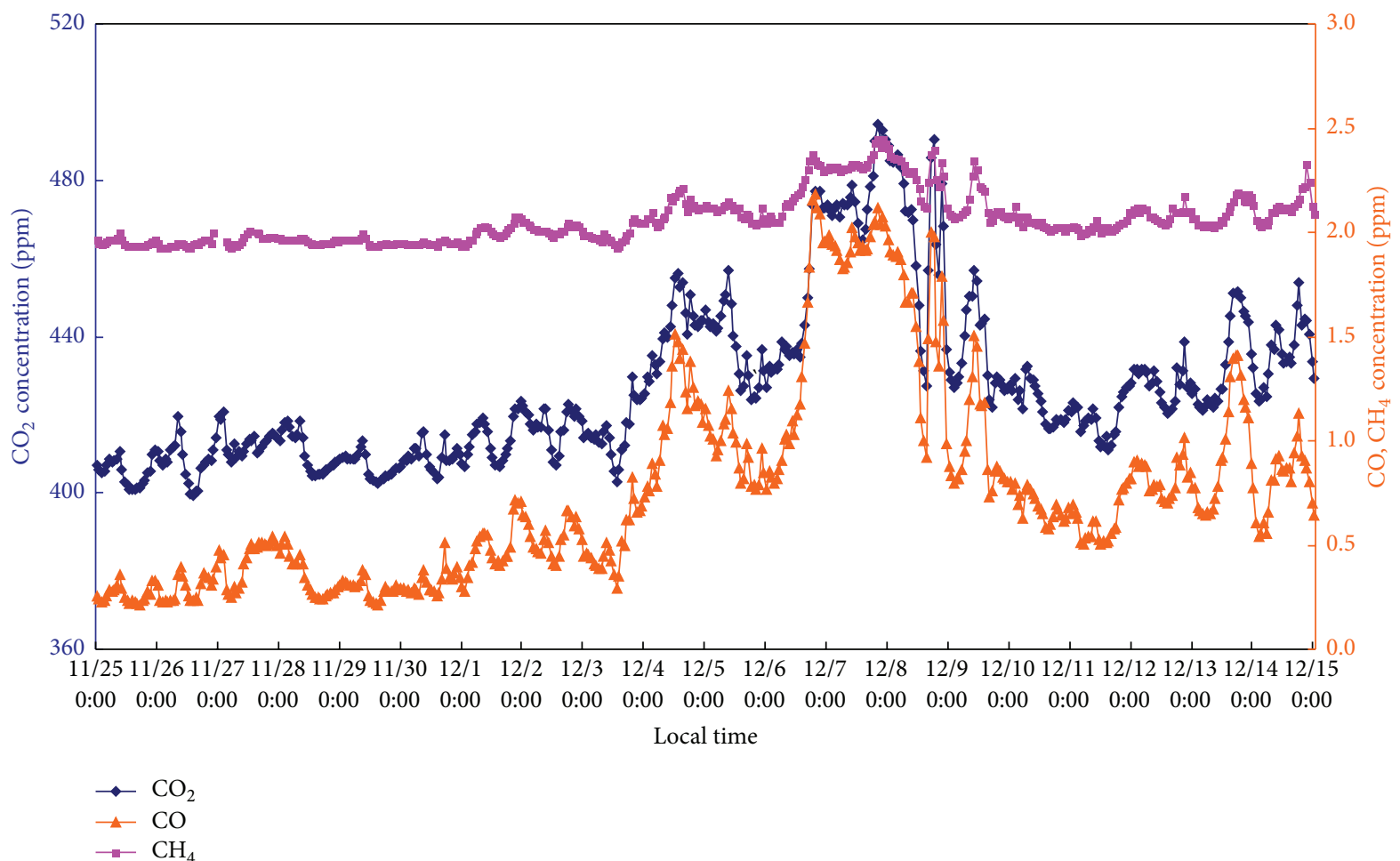

FIGURE 5: Hourly mean concentrations of $\mathrm{CO}_{2}, \mathrm{CO}$, and $\mathrm{CH}_{4}$ at Lin'an background station.

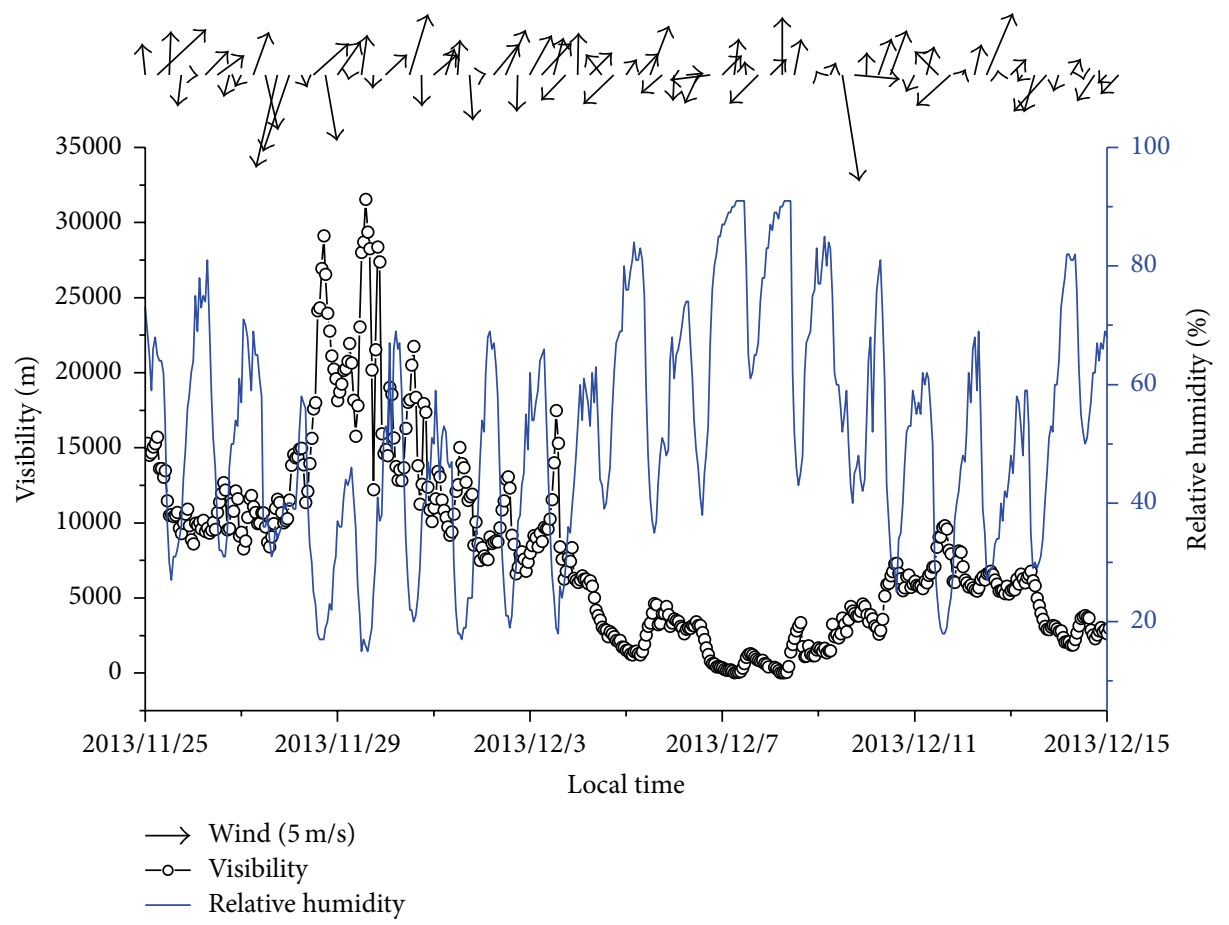

FIGURE 6: Hourly visibility, relative humidity, surface wind speed, and wind direction at Linan station.

droplets, $\mathrm{PM}_{2.5}$ concentration dropped evidently in these two durations, while the concentrations of $\mathrm{CO}_{2}, \mathrm{CO}$, and $\mathrm{CH}_{4}$ presented much less decrements (Figures 3 and 5). Given that all the simultaneous measurements of these pollutants were conducted at the same site, the fog droplet size distribution could be considered the same during the entire fog deposition process; the discrepancy between concentration reductions of particle and the other three gases might be because the 


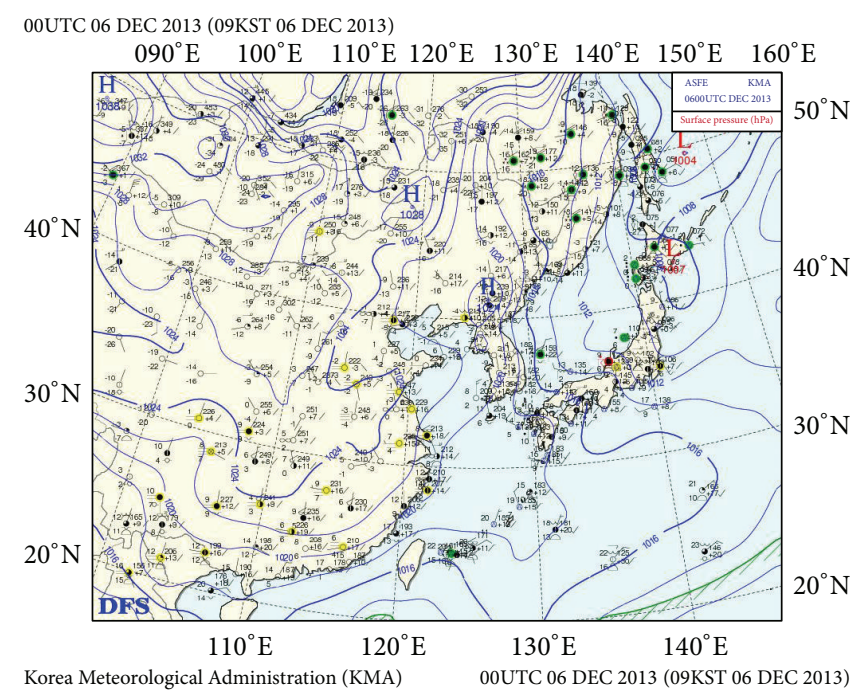

00UTC 08 DEC 2013 (09KST 08 DEC 2013)
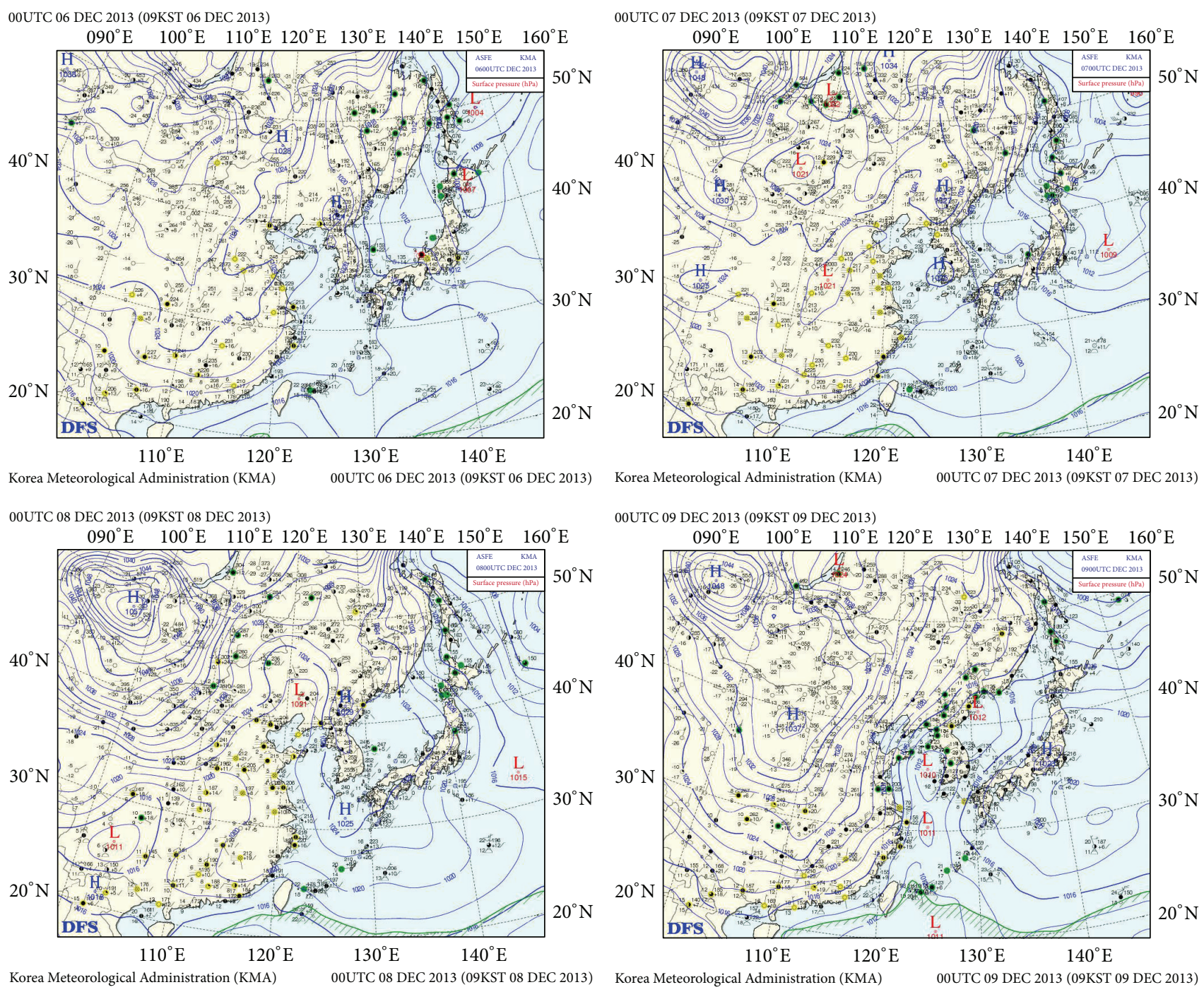

00UTC 09 DEC 2013 (09KST 09 DEC 2013)

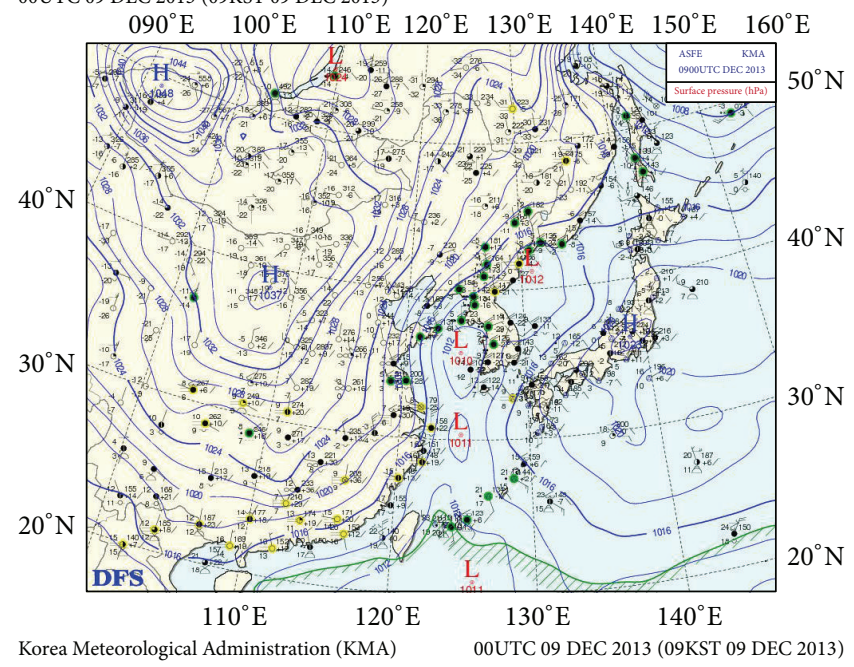

Figure 7: Surface weather patterns over eastern Asia at 08:00 (local time) on 6, 7, 8, and 9 Dec. 2013 (from http://web.kma.go.kr/).

particle wet scavenging efficiency would be much more dominant than that of $\mathrm{CO}_{2}, \mathrm{CO}$, and $\mathrm{CH}_{4}$ as the latter is generally affected by gas dissolution and surface adsorption $[45,46]$.

Similar to those reported in previous studies $[2,10,15,17]$, weak surface wind speed was also observed at Linan station during this strong haze event. The average wind speed was $1.57 \pm 0.84 \mathrm{~m} \mathrm{~s}^{-1}$ from 00:00 on 4 Dec. to 08:00 on 9 Dec., it was lower than $2.10 \pm 1.25 \mathrm{~m} \mathrm{~s}^{-1}$ in prehaze period from 00:00 on 25 Nov. to 23:00 on 30 Nov., and it remained at the level of $1.48 \pm 0.87 \mathrm{~m} \mathrm{~s}^{-1}$ in posthaze period from 00:00 on 10 Dec. to 23:00 on 14 Dec. (Figure 6). A weak surface high-pressure system persisted in YRD from 4 to 6 Dec. 2013 (Figure 7), and, at 08:00 in the morning, thermal inversion was observed under 200 masl (Figure 8), so that the weather condition was disadvantageous for dispersion. On 7 Dec., surface high-pressure system became weaker, and on 8 Dec. saddle ground pressure field controlled this region; thermal inversion occurred between 200 and 800 masl, so the dispersion condition remained poor. From 08:00 on 9 Dec. a strong Mongolia anticyclone came over; thus the surface wind speed increased significantly and the thermal inversion disappeared, which were deemed to benefit the dispersion and circulation of atmospheric pollutants so that their occurrence levels dropped considerably as shown in Figures 3 and 5.

3.5. Diurnal Variation of $\mathrm{CO}_{2}, \mathrm{CO}, \mathrm{CH}_{4}, \mathrm{BC}$, and $\mathrm{PM}_{2.5}$. Figure 9 demonstrated the diurnal variation of concentrations of $\mathrm{CO}_{2}, \mathrm{CO}, \mathrm{CH}_{4}, \mathrm{BC}$, and $\mathrm{PM}_{2.5}$ between prehaze (25 30 Nov. 2013) and strong haze (4 9 Dec. 2013) periods. In prehaze period, the diurnal variations of $\mathrm{CO}_{2}, \mathrm{BC}$, and $\mathrm{PM}_{2.5}$ seemed to be significant with the diurnal amplitudes of $10.4 \mathrm{ppm}\left(\mathrm{CO}_{2}\right), 2.4 \mu \mathrm{g} \mathrm{m}^{-3}(\mathrm{BC})$, and $17.7 \mu \mathrm{g} \mathrm{m}^{-3}\left(\mathrm{PM}_{2.5}\right)$, respectively, while the diurnal amplitudes of $\mathrm{CO}$ and $\mathrm{CH}_{4}$ were only $0.10 \mathrm{ppm}$ and $0.036 \mathrm{ppm}$, respectively, though the diurnal variations were still slightly observable. The diurnal 


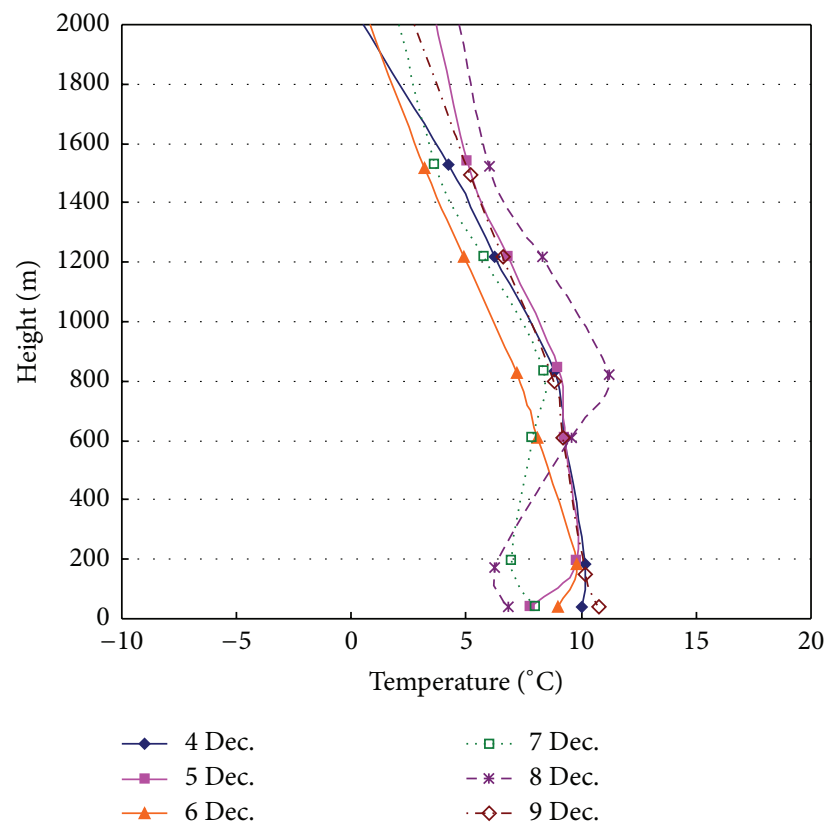

Figure 8: Temperature soundings at Hangzhou station at 08:00 (local time) on 4 9 Dec. 2013 (from http://weather.uwyo.edu/upperair/ sounding.html).

distribution of $\mathrm{CO}_{2}$ concentration showed a single-peak pattern with the peak value occurring at 8:00; $\mathrm{CH}_{4}$ concentration exhibited double peaks at 9:00 and 22:00; $\mathrm{BC}$ and $\mathrm{PM}_{2.5}$ concentrations presented three peaks appearing at 9:00, 18:00, and 23:00. The diurnal $\mathrm{CO}_{2}$ distribution in prehaze period was similar to the observations during winter season at this station in 2009 2011 [42] which indicated that the diurnal $\mathrm{CO}_{2}$ variation was affected predominantly by meteorological dispersion conditions and sources/sinks [42, 47]. Due to the active photosynthetic/respiration fluxes in all seasons at Lin'an station, the minimum concentration appeared in the afternoon when the diffusion condition was more favorable and the photosynthetic $\mathrm{CO}_{2}$ uptake was strong, while the higher concentration appeared at dawn when the boundary layer became stable and the respiration was strong. The diurnal variations of $\mathrm{CH}_{4}, \mathrm{BC}$, and $\mathrm{PM}_{2.5}$ were also consistent with the diurnal cycle of the boundary layer which led to a peak in the morning and a minimum value in the afternoon. Moreover, due to the anthropogenic sources, especially from the vehicular emission at the morning and evening rush hours, the concentrations of $\mathrm{CO}, \mathrm{BC}$, and $\mathrm{PM}_{2.5}$ presented dual peaks at 9:00 and 18:00, respectively, which was similar to that observed at other locations $[4,48] . \mathrm{CH}_{4}$ had not shown that peak in the afternoon possibly because of the photochemical reaction induced by $\mathrm{OH}^{\bullet}$ [41]. At 22:00 23:00, the concentrations of $\mathrm{CH}_{4}, \mathrm{CO}, \mathrm{BC}$, and $\mathrm{PM}_{2.5}$ presented another peak, which might be ascribed to high accumulation rates at nighttime [49]; after that, due to the decrease of anthropogenic emissions, the concentrations declined until early morning, though the mixing height and wind speed remained constant and low [50].

During strong haze period, more significant diurnal variations were observed. The concentrations of all these five pollutants jumped dramatically during each hour of the day, and the diurnal amplitude rose up to $16.4 \mathrm{ppm}\left(\mathrm{CO}_{2}\right)$, $0.33 \mathrm{ppm}$ (CO), $0.086 \mathrm{ppm}\left(\mathrm{CH}_{4}\right), 6.9 \mu \mathrm{g} \mathrm{m}^{-3}$ (BC), and 106.6 $\mu \mathrm{g} \mathrm{m}^{-3}\left(\mathrm{PM}_{2.5}\right)$, respectively. The diurnal distributions of these pollutants displayed a trimodal pattern, reaching the peak value at 9:00 10:00, 17:00 18:00, and 21:00 22:00, respectively, with the maximum value occurring at 17:00 18:00 and the minimum value occurring at 5:00 6:00, except for $\mathrm{CO}_{2}$ whose minimum value still occurred at 15:00. It is understandable that $\mathrm{CO}_{2}$ concentration reached the minimum in the afternoon which was the same as in the prehaze period due to the stronger photosynthesis uptake during that time. For $\mathrm{CO}, \mathrm{CH}_{4}, \mathrm{BC}$, and $\mathrm{PM}_{2.5}$, the minimum concentrations occurred in the early morning, which could be explained by the fact that the emission intensity of these pollutants could be much lesser during the late nighttime. It was also clear that the occurrence levels of these four pollutants had been increased considerably from early morning to midnight. This trend could be also attributed to stronger industrial activities, traffic emission, and lesser favorable dispersion conditions. In addition, it could not be ignored that the regional short- and medium-range transport had contributed to the peaking of these four pollutants in the afternoon.

3.6. Correlation of $\mathrm{CO}_{2}, \mathrm{CO}, \mathrm{CH}_{4}$, and $\mathrm{BC}$. Table 1 exhibited the correlation coefficient of concentrations of $\mathrm{BC}, \mathrm{CO}$, $\mathrm{CO}_{2}$, and $\mathrm{CH}_{4}$. It was manifestly seen that the correlation coefficient in haze period was significantly higher than that in prehaze period, which was also observed at Mt. Fuji, Japan, during smoke event [19]. The concentrations of BC, $\mathrm{CO}, \mathrm{CO}_{2}$, and $\mathrm{CH}_{4}$ seemed to experience a more similar evolution in haze period. $\Delta \mathrm{CO} / \Delta \mathrm{CO}_{2}$ (slope of hourly mean 

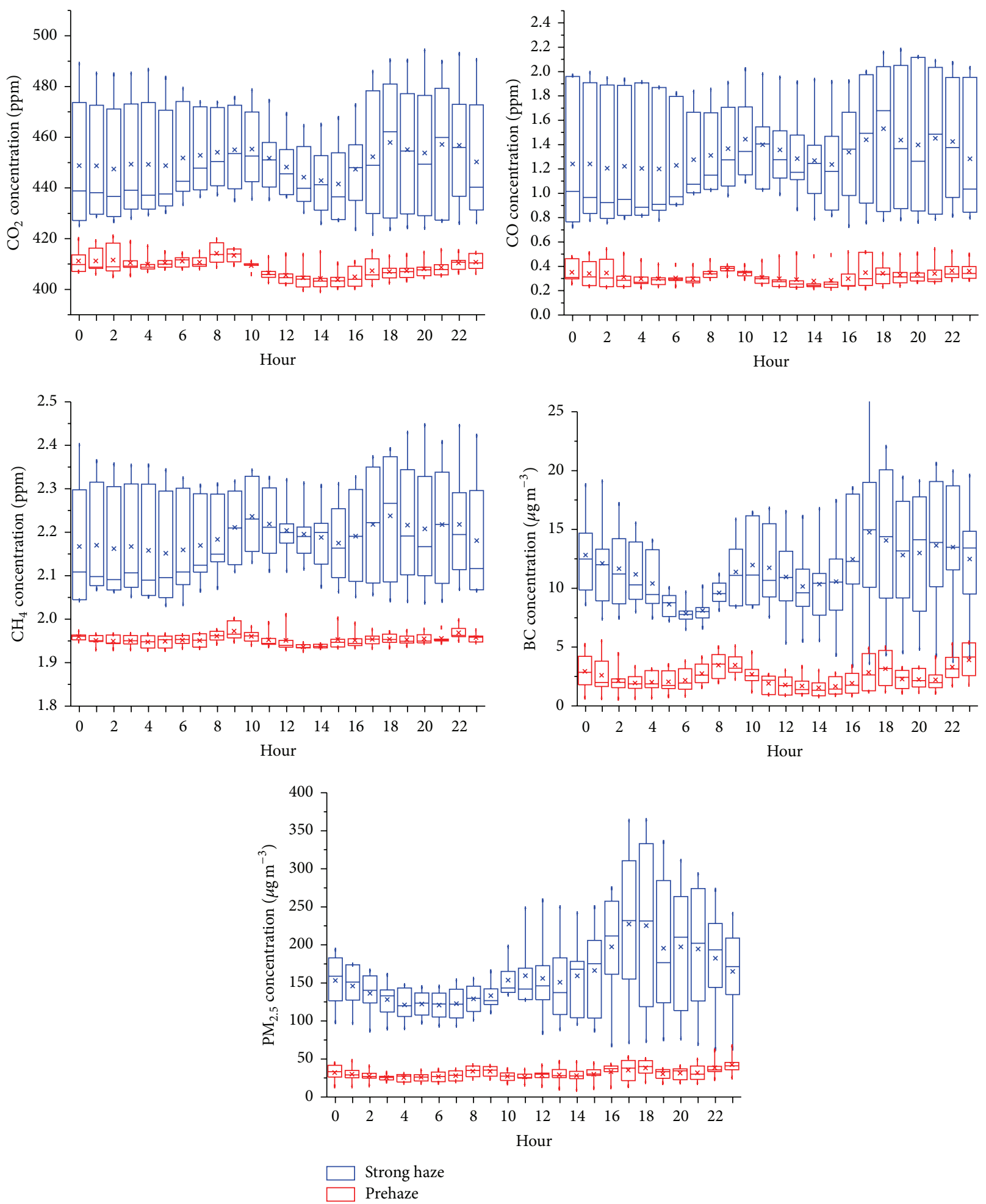

FIGURE 9: Diurnal concentration variations of $\mathrm{CO}_{2}, \mathrm{CO}, \mathrm{CH}_{4}, \mathrm{BC}$, and $\mathrm{PM}_{2.5}$ at Lin'an regional background station.

concentrations of $\mathrm{CO}$ and $\mathrm{CO}_{2}$ ) and $\Delta \mathrm{CH}_{4} / \Delta \mathrm{CO}_{2}$ in haze period were higher than those in prehaze period. Generally, higher $\Delta \mathrm{CO} / \Delta \mathrm{CO}_{2}$ indicated relatively lower combustion efficiency and it is also known that the combustion efficiency of biomass burning is normally lower than that of fossil fuel as biomass burning is more of smoldering fires [25]. In addition, modified combustion efficiency (MCE, defined as $\left.\Delta \mathrm{CO}_{2} / \Delta \mathrm{CO}+\Delta \mathrm{CO}_{2}\right)$ has been adopted and it shows that MCE in haze episode (0.979) was also lower than that in prehaze period (0.985). Streets et al. [51] had 
TABLE 1: Correlation coefficient (CC) of concentrations of BC, $\mathrm{CO}, \mathrm{CO}_{2}$, and $\mathrm{CH}_{4}$ and the ratio of $\Delta \mathrm{BC} / \Delta \mathrm{CO}, \Delta \mathrm{CO} / \Delta \mathrm{CO}_{2}$, and $\Delta \mathrm{CH}_{4} / \Delta \mathrm{CO}_{2}$ at Linan station.

\begin{tabular}{lcc}
\hline & Prehaze period & Haze period \\
\hline $\mathrm{CC}$ between $\mathrm{BC}$ and $\mathrm{CO}^{\#}$ & 0.5346 & 0.7534 \\
$\mathrm{CC}$ between $\mathrm{CO}$ and $\mathrm{CO}_{2}^{\#}$ & 0.7922 & 0.9599 \\
$\mathrm{CC}$ between $\mathrm{CH}_{4}$ and $\mathrm{CO}_{2}^{\#}$ & 0.5769 & 0.9460 \\
$\Delta \mathrm{BC} / \Delta \mathrm{CO}\left(\mu \mathrm{g} \mathrm{m}^{-3} / \mu \mathrm{g} \mathrm{m}^{-3}\right)$ & 0.0075 & 0.0058 \\
$\Delta \mathrm{CO} / \Delta \mathrm{CO}_{2}(\mathrm{ppm} / \mathrm{ppm})$ & 0.0150 & 0.0217 \\
$\Delta \mathrm{CH}_{4} / \Delta \mathrm{CO}_{2}(\mathrm{ppm} / \mathrm{ppm})$ & 0.0022 & 0.0054 \\
\hline
\end{tabular}

${ }^{\#} P<0.0001$.

reported the emission ratio of $\mathrm{CH}_{4} / \mathrm{CO}_{2}$ derived from the emission inventory compiled in 2000 was $1.80(\mathrm{Gg} / \mathrm{Tg})$ from biomass burning, higher than $1.38(\mathrm{Gg} / \mathrm{Tg})$ from fossil fuel combustion in YRD. The $\Delta \mathrm{BC} / \Delta \mathrm{CO}$ ratio in prehaze period was $0.0075 \mu \mathrm{g} \mathrm{m}^{-3} / \mu \mathrm{g} \mathrm{m}^{-3}$, close to the value of $0.008 \mu \mathrm{g} \mathrm{m}^{-3} / \mu \mathrm{g} \mathrm{m}^{-3}$ in northern China in 2005 [52], while in haze period the ratio dropped to $0.0058 \mu \mathrm{g} \mathrm{m}^{-3} / \mu \mathrm{g} \mathrm{m}^{-3}$. Smoldering biomass burning in YRD region is known to be dominant. During the haze period, significantly additional $\mathrm{CO}$ and $\mathrm{BC}$ could be emitted due to the incomplete biomass burning, while more $\mathrm{BC}$ might have been removed via wet scavenging process by fog droplets through the internal mixture with water soluble species when the air masses had been long transported [19], leading to lower $\Delta \mathrm{BC} / \Delta \mathrm{CO}$ ratio in the haze episode. Consistent with the findings from air mass backward trajectory analysis, $\Delta \mathrm{CO} / \Delta \mathrm{CO}_{2}, \Delta \mathrm{CH}_{4} / \Delta \mathrm{CO}_{2}$, and $\Delta \mathrm{BC} / \triangle \mathrm{CO}$ all therefore implied that the biomass burning in this region had contributed more to the formation of haze occurring during 4-9 Dec. 2013.

\section{Conclusion}

Air mass backward trajectory and fire spot distribution showed that medium/long range transboundary transport of air masses coming from biomass burning regions contributed to the formation of haze aerosols in Lin'an on 4 9 Dec. 2013 when a heavy air pollution attacked Yangtze River Delta, China. The stagnant meteorological conditions, including low surface wind speed, thermal inversion in planetary boundary layer, and weak high-pressure system, attributed to the accumulation of pollutants in haze period. Higher $\mathrm{PM}_{2.5}$ mass concentration and mass ratio of $\mathrm{PM}_{2.5} / \mathrm{PM}_{10}$ in haze period indicated more $\mathrm{PM}_{2.5}$ had been formed and contributed to the inhalable particulate matter during such a haze pollution event in this region. Lower mass ratio of $\mathrm{BC} / \mathrm{PM}_{2.5}$ in haze period might explain that much more secondary aerosol had been formed and accumulated.

In haze period, due to the influence of stronger industrial activities, traffic emission, lesser favorable dispersion conditions, and regional transboundary transport, the diurnal variation of $\mathrm{CO}_{2}, \mathrm{CO}, \mathrm{CH}_{4}, \mathrm{BC}$, and $\mathrm{PM}_{2.5}$ concentration presented a similar distribution, displaying a trimodal pattern. The correlation analysis of concentrations of $\mathrm{CO}_{2}, \mathrm{CO}, \mathrm{CH}_{4}$, and $\mathrm{BC}$ indicated that biomass burning might play a role in this polluted episode. The lower correlation coefficient of $\mathrm{BC}$ and $\mathrm{CO}$ than that of $\mathrm{CO}$ and $\mathrm{CO}_{2}, \mathrm{CH}_{4}$ and $\mathrm{CO}_{2}$ in haze period, suggested more $\mathrm{BC}$ could be possibly removed through wet scavenging process by fog droplets on $6 \sim 8 \mathrm{Dec}$.

\section{Competing Interests}

The authors declare that they have no competing interests.

\section{Acknowledgments}

The authors express their great thanks to the staff of Lin'an Regional Atmospheric Background Station who have contributed to observations of greenhouse gases and the staff of key laboratory for atmospheric chemistry (CMA) who performed calibration and quality control of the data. This work was jointly supported by the "Strategic Priority Research Program (B)" of the Chinese Academy of Sciences (Grant no. XDB05020403), the China Special Fund for Meteorological Research in the Public Interest (no. GYHY201206011), Chinese National Natural Science Foundation (41303091), Zhejiang Meteorological Science project (2013ZD06), Zhejiang Provincial Applied Research Program for Commonweal Technology project (2015C33011), Ningbo Municipal Natural Science Foundation (2014A610096), and Ningbo Municipal Key Project (2012B10042).

\section{References}

[1] H. H. Du, L. D. Kong, T. T. Cheng et al., "Insights into summertime haze pollution events over Shanghai based on online water-soluble ionic composition of aerosols," Atmospheric Environment, vol. 45, no. 29, pp. 5131-5137, 2011.

[2] Q. Y. Fu, G. S. Zhuang, J. Wang et al., "Mechanism of formation of the heaviest pollution episode ever recorded in the Yangtze River Delta, China," Atmospheric Environment, vol. 42, no. 9, pp. 2023-2036, 2008.

[3] H. Q. Kang, B. Zhu, J. F. Su, H. Wang, Q. Zhang, and F. Wang, "Analysis of a long-lasting haze episode in Nanjing, China," Atmospheric Research, vol. 120-121, pp. 78-87, 2013.

[4] Z.-M. Xiao, Y.-F. Zhang, S.-M. Hong et al., "Estimation of the main factors influencing haze, based on a long-term monitoring campaign in Hangzhou, China," Aerosol and Air Quality Research, vol. 11, no. 7, pp. 873-882, 2011.

[5] Z. Y. Chen, W. Q. Liu, B. Heese et al., "Aerosol optical properties observed by combined Raman-elastic backscatter lidar in winter 2009 in Pearl River Delta, south China," Journal of Geophysical Research, vol. 119, no. 5, pp. 2496-2510, 2014.

[6] J. H. Tan, J. C. Duan, K. B. He et al., "Chemical characteristics of $\mathrm{PM}_{2.5}$ during a typical haze episode in Guangzhou," Journal of Environmental Sciences, vol. 21, no. 6, pp. 774-781, 2009.

[7] G. Zhang, X. Bi, L. Y. Chan, X. Wang, G. Sheng, and J. Fu, "Sizesegregated chemical characteristics of aerosol during haze in an urban area of the Pearl River Delta region, China," Urban Climate, vol. 4, pp. 74-84, 2013.

[8] Z. Q. Sun, Y. J. Mu, Y. J. Liu, and L. Shao, "A comparison study on airborne particles during haze days and non-haze days in Beijing," Science of the Total Environment, vol. 456-457, pp. 1-8, 2013. 
[9] W. Xu, H. Chen, D. Li, F. Zhao, and Y. Yang, "A case study of aerosol characteristics during a haze episode over Beijing," Procedia Environmental Sciences, vol. 18, pp. 404-411, 2013.

[10] X. J. Zhao, P. S. Zhao, J. Xu et al., "Analysis of a winter regional haze event and its formation mechanism in the North China Plain," Atmospheric Chemistry and Physics, vol. 13, no. 11, pp. 5685-5696, 2013.

[11] C. K. Chan and X. H. Yao, "Air pollution in mega cities in China," Atmospheric Environment, vol. 42, no. 1, pp. 1-42, 2008.

[12] D. Chang, Y. Song, and B. Liu, "Visibility trends in six megacities in China 1973-2007," Atmospheric Research, vol. 94, no. 2, pp. 161-167, 2009.

[13] I. Mordukhovich, E. Wilker, H. Suh et al., "Black carbon exposure, oxidative stress genes, and blood pressure in a repeatedmeasures study," Environmental Health Perspectives, vol. 117, no. 11, pp. 1767-1772, 2009.

[14] M. Lodovici and E. Bigagli, "Oxidative stress and air pollution exposure," Journal of Toxicology, vol. 2011, Article ID 487074, 9 pages, 2011.

[15] J. Quan, Q. Zhang, H. He, J. Liu, M. Huang, and H. Jin, "Analysis of the formation of fog and haze in North China Plain (NCP)," Atmospheric Chemistry and Physics, vol. 11, no. 15, pp. 82058214, 2011.

[16] W. J. Li, L. Y. Shao, and P. R. Buseck, "Haze types in Beijing and the influence of agricultural biomass burning," Atmospheric Chemistry and Physics, vol. 10, no. 17, pp. 8119-8130, 2010.

[17] K. Huang, G. Zhuang, Y. Lin et al., "Typical types and formation mechanisms of haze in an Eastern Asia megacity, Shanghai," Atmospheric Chemistry and Physics, vol. 12, no. 1, pp. 105-124, 2012.

[18] V. T. F. Cheung and T. Wang, "Observational study of ozone pollution at a rural site in the Yangtze Delta of China," Atmospheric Environment, vol. 35, no. 29, pp. 4947-4958, 2001.

[19] N. Kaneyasu, Y. Igarashi, Y. Sawa et al., "Chemical and optical properties of 2003 Siberian forest fire smoke observed at the summit of Mt. Fuji, Japan," Journal of Geophysical Research Atmospheres, vol. 112, no. 13, Article ID D13214, 2007.

[20] T. W. Kirchstetter, T. Novakov, P. V. Hobbs, and B. Magi, "Airborne measurements of carbonaceous aerosols in southern Africa during the dry biomass burning season," Journal of Geophysical Research D: Atmospheres, vol. 108, no. 13, pp. 1-12, 2003.

[21] A. P. Sullivan, A. S. Holden, L. A. Patterson et al., "A method for smoke marker measurements and its potential application for determining the contribution of biomass burning from wildfires and prescribed fires to ambient $\mathrm{PM}_{2.5}$ organic carbon," Journal of Geophysical Research Atmospheres, vol. 113, no. 22, Article ID D22302, 2008.

[22] Y. Qin and S. D. Xie, "Spatial and temporal variation of anthropogenic black carbon emissions in China for the period 1980-2009," Atmospheric Chemistry and Physics, vol. 12, no. 11, pp. 4825-4841, 2012.

[23] P. Forster, V. Ramaswamy, P. Artaxo et al., "Changes in atmospheric constituents and in radiative forcing," in Climate Change 2007: The Physical Science Basis. Contribution of Working Group 1 to the Fourth Assessment Report of the Intergovernmental Panel on Climate Change, pp. 511-513, Cambridge University Press, Cambridge, UK, 2007.

[24] S. Sathitkunarat, P. Wongwises, R. Pan-Aram, and M. Zhang, "Carbon monoxide emission and concentration models for Chiang Mai urban area," Advances in Atmospheric Sciences, vol. 23, no. 6, pp. 901-908, 2006.
[25] R. J. Yokelson, I. T. Bertschi, T. J. Christian, P. V. Hobbs, D. E. Ward, and W. M. Hao, "Trace gas measurements in nascent, aged, and cloud-processed smoke from African savanna fires by airborne Fourier transform infrared spectroscopy (AFTIR)," Journal of Geophysical Research, vol. 108, no. 13, 2003.

[26] N. Takegawa, Y. Kondo, M. Koike et al., "Removal of $\mathrm{NO}_{\mathrm{x}}$ and $\mathrm{NO}_{y}$ in Asian outflow plumes: aircraft measurements over the western Pacific in Januray 2002," Journal of Geophysical Research D: Atmospheres, vol. 109, no. 23, pp. 1-16, 2004.

[27] S. Han, Y. Kondo, N. Oshima et al., "Temporal variations of elemental carbon in Beijing," Journal of Geophysical Research, vol. 114, no. 23, 2009.

[28] Y. Kondo, Y. Komazaki, Y. Miyazaki et al., "Temporal variations of elemental carbon in Tokyo," Journal of Geophysical Research, vol. 111, no. 12, 2006.

[29] S. Song, Y. Wu, J. Xu et al., "Black carbon at a roadside site in Beijing: temporal variations and relationships with carbon monoxide and particle number size distribution," Atmospheric Environment, vol. 77, pp. 213-221, 2013.

[30] Y. Wang, X. Wang, Y. Kondo, M. Kajino, J. W. Munger, and J. Hao, "Black carbon and its correlation with trace gases at a rural site in Beijing: top-down constraints from ambient measurements on bottom-up emissions," Journal of Geophysical Research, vol. 116, no. 24, 2011.

[31] X. H. Zhou, J. Gao, T. Wang, W. Wu, and W. Wang, "Measurement of black carbon aerosols near two Chinese megacities and the implications for improving emission inventories," Atmospheric Environment, vol. 43, no. 25, pp. 3918-3924, 2009.

[32] T. R. Zhang, J. W. Martin, C. G. David et al., "New field-based agricultural biomass burning trace gas, $\mathrm{PM}_{2.5}$, and black carbon emission ratios and factors measured in situ at crop residue fires in Eastern China," Atmospheric Environment, vol. 121, pp. 22-34, 2015.

[33] Y. Kondo, N. Oshima, M. Kajino et al., "Emissions of black carbon in East Asia estimated from observations at a remote site in the East China Sea," Journal of Geophysical Research, vol. 116, no. 16, 2011.

[34] S. P. Seung, M. S. Bae, J. J. Schauer et al., "Evaluation of the TMO and TOT methods for OC and EC measurements and their characteristics in PM2.5 at an urban site of Korea during ACE-Asia," Atmospheric Environment, vol. 39, no. 28, pp. 51015112, 2005.

[35] F. Wang, Z. Guo, T. Lin, and N. L. Rose, "Seasonal variation of carbonaceous pollutants in $\mathrm{PM}_{2.5}$ at an urban 'supersite' in Shanghai, China," Chemosphere, vol. 146, pp. 238-244, 2016.

[36] D. S. Ji, J. K. Zhang, J. He et al., "Characteristics of atmospheric organic and elemental carbon aerosols in urban Beijing, China," Atmospheric Environment, vol. 125, pp. 293-306, 2016.

[37] Y. Morino, T. Ohara, J. Xu et al., "Diurnal variations of fossil and nonfossil carbonaceous aerosols in Beijing," Atmospheric Environment, vol. 122, pp. 349-356, 2015.

[38] J. Liu, J. Li, Y. Zhang et al., "Source apportionment using radiocarbon and organic tracers for $\mathrm{PM}_{2.5}$ carbonaceous aerosols in Guangzhou, South China: contrasting local- and regional-scale Haze events," Environmental Science and Technology, vol. 48, no. 20, pp. 12002-12011, 2014.

[39] M. Zhou, C. Chen, L. Qiao et al., "The chemical characteristics of particulate matters in Shanghai during heavy air pollution episode in Central and Eastern China in January 2013," Acta Scientiae Circumstantiae, vol. 33, no. 11, pp. 3118-3126, 2013. 
[40] A. D. A. Hansen, The Aethalometer ${ }^{\mathrm{TM}}$ Operating Manual, 2005, http://www.mageesci.com/ images/stories/docs/Aethalometer book_2005.07.03.pdf.

[41] S.-X. Fang, L.-X. Zhou, K. A. Masarie, L. Xu, and C. W. Rella, "Study of atmospheric $\mathrm{CH}_{4}$ mole fractions at three WMO/GAW stations in China," Journal of Geophysical Research Atmospheres, vol. 118, no. 10, pp. 4874-4886, 2013.

[42] S. X. Fang, L. X. Zhou, P. P. Tans et al., "In situ measurement of atmospheric $\mathrm{CO}_{2}$ at the four WMO/GAW stations in China," Atmospheric Chemistry and Physics, vol. 14, no. 5, pp. 2541-2554, 2014.

[43] L. Giglio, J. Descloitres, C. O. Justice, and Y. J. Kaufman, "An enhanced contextual fire detection algorithm for MODIS," Remote Sensing of Environment, vol. 87, no. 2-3, pp. 273-282, 2003.

[44] R.-J. Huang, Y. L. Zhang, C. Bozzetti et al., "High secondary aerosol contribution to particulate pollution during haze events in China," Nature, vol. 514, pp. 218-222, 2014.

[45] J. He and R. Balasubramanian, "Rain-aerosol coupling in the tropical atmosphere of Southeast Asia: distribution and scavenging ratios of major ionic species," Journal of Atmospheric Chemistry, vol. 60, no. 3, pp. 205-220, 2008.

[46] J. He and R. Balasubramanian, "A study of precipitation scavenging of semivolatile organic compounds in a tropical area," Journal of Geophysical Research Atmospheres, vol. 114, no. 12, Article ID D12201, 2009.

[47] F. Artuso, P. Chamard, S. Piacentino et al., "Influence of transport and trends in atmospheric $\mathrm{CO}_{2}$ at Lampedusa," Atmospheric Environment, vol. 43, no. 19, pp. 3044-3051, 2009.

[48] X. Zhao, X. Zhang, X. Xu, J. Xu, W. Meng, and W. Pu, "Seasonal and diurnal variations of ambient $\mathrm{PM}_{2.5}$ concentration in urban and rural environments in Beijing," Atmospheric Environment, vol. 43, no. 18, pp. 2893-2900, 2009.

[49] L. Gao, R. Zhang, Z. Han et al., "A modeling study of a typical winter $\mathrm{PM}_{2.5}$ pollution episode in a city in Eastern China," Aerosol and Air Quality Research, vol. 14, no. 1, pp. 311-322, 2014.

[50] S. Tiwari, A. K. Srivastava, D. S. Bisht, P. Parmita, M. K. Srivastava, and S. D. Attri, "Diurnal and seasonal variations of black carbon and $\mathrm{PM}_{2.5}$ over New Delhi, India: influence of meteorology," Atmospheric Research, vol. 125-126, pp. 50-62, 2013.

[51] D. G. Streets, T. C. Bond, G. R. Carmichael et al., "An inventory of gaseous and primary aerosol emissions in Asia in the year 2000," Journal of Geophysical Research, vol. 108, no. 21, 2003.

[52] C. Li, L. T. Marufu, R. R. Dickerson et al., "In situ measurements of trace gases and aerosol optical properties at a rural site in northern China during East Asian Study of Tropospheric Aerosols: an International Regional Experiment 2005," Journal of Geophysical Research Atmospheres, vol. 112, no. 22, Article ID D22S04, 2007. 

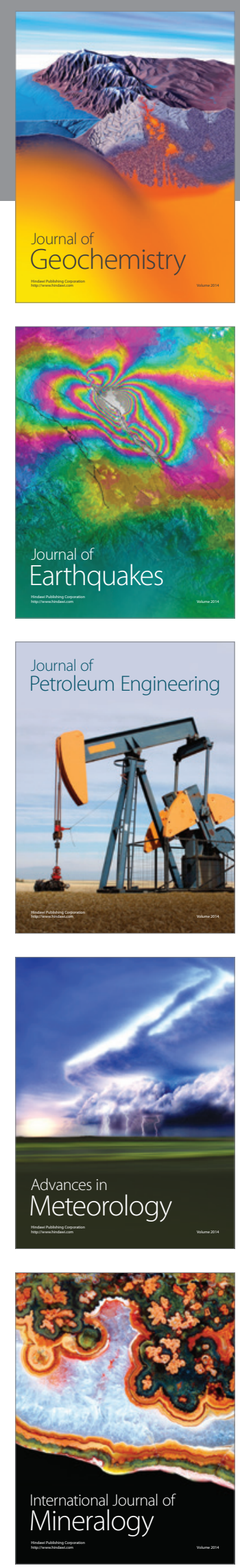
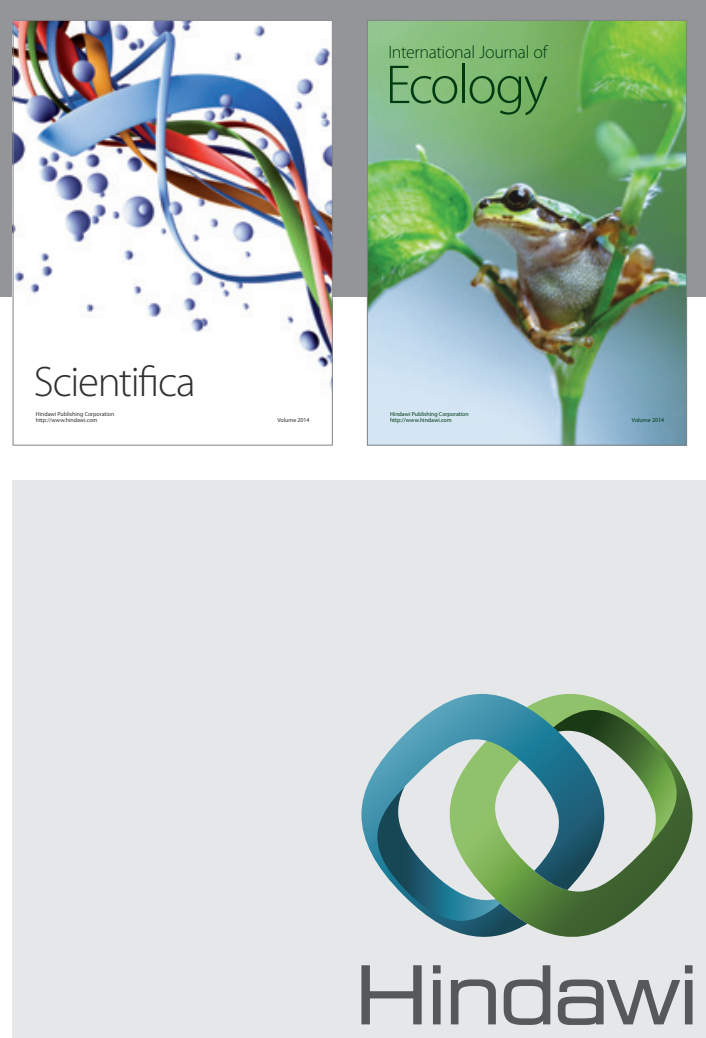

Submit your manuscripts at

http://www.hindawi.com
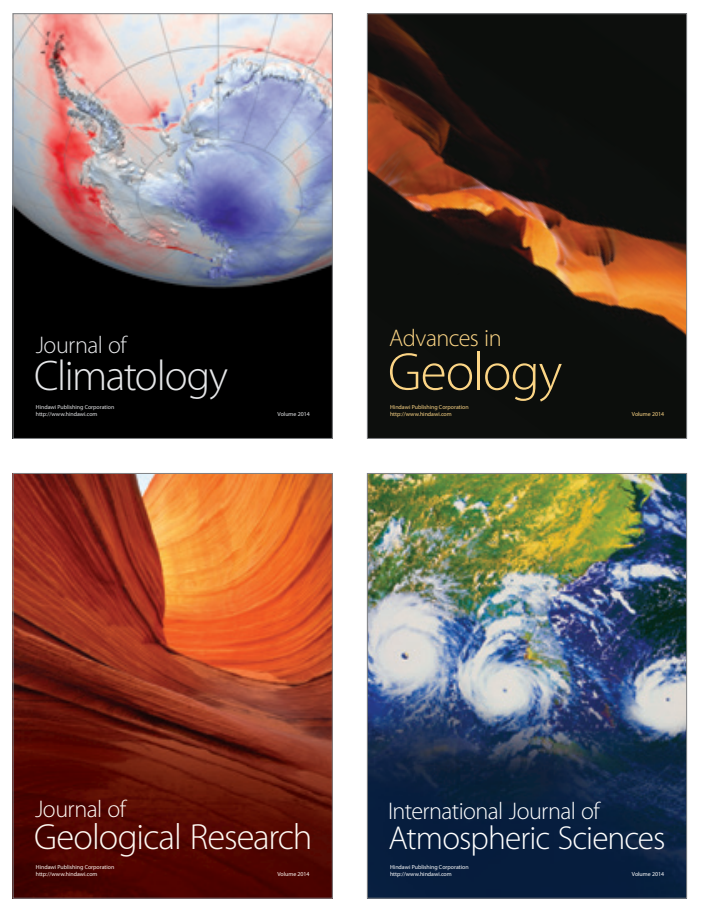

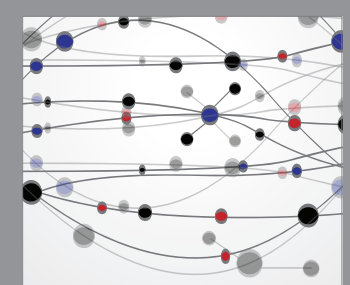

The Scientific

\section{World Journal}
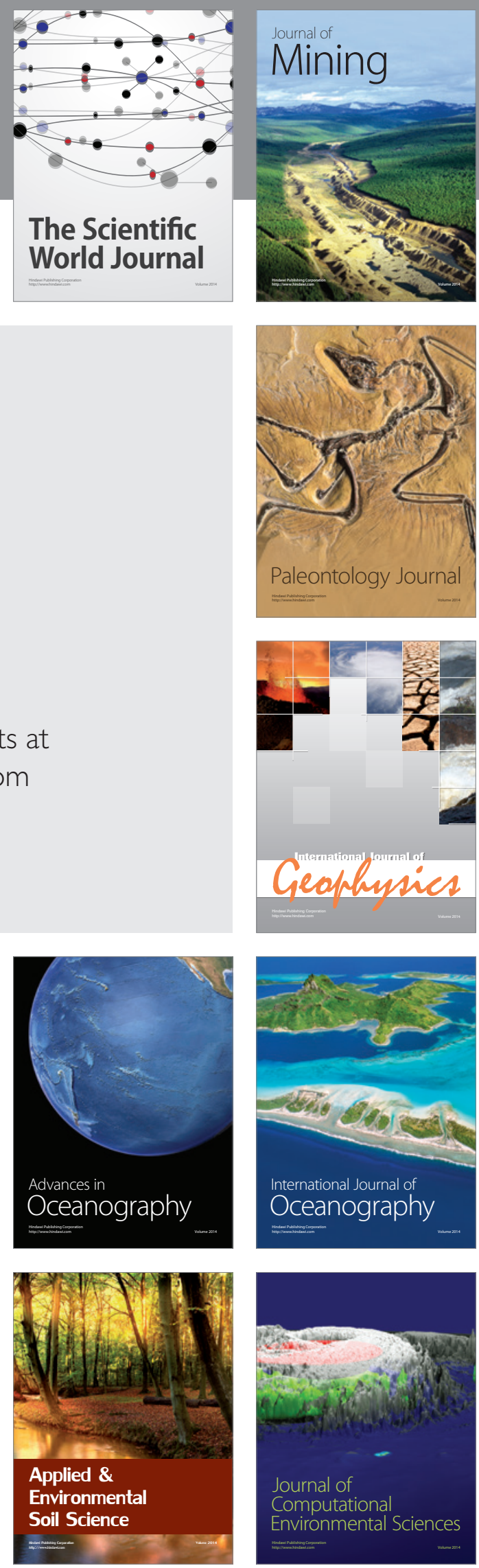